\title{
When is Emotional Labor Less Detrimental to Employee Well-Being? The Moderating Effect of Rewards and Motivational Forces of Display Rules
}

\author{
Shanshan Qian \\ Towson University \\ Chao Miao \\ Salisbury University
}

Prior research suggested engaging in emotional labor for financial gain is generally dissatisfying and is associated with negative mental outcomes. In this conceptual paper, we address the research question: when is emotional labor less detrimental to employee well-being? We investigate how rewards as well as valence and expectancy of display rules moderate the associations between surface acting and emotional exhaustion and job satisfaction. We discuss the differential moderating effects of financial and nonfinancial rewards on the relationships between surface acting and emotional exhaustion and job satisfaction for people in different professions. Our research provides multiple avenues for future research.

\section{INTRODUCTION}

Research in the emotional labor field has continued to develop for almost three decades. This is because the number of people employed in service sector in the United States climbs each year; however, the manufacturing industry faces continuous decline (Mehring, 2006). Because of this consistent growth of employment in service industry, service industry plays a vital role in today's economy. Recent reports showed that seventy percent of gross domestic product in the United States and European Countries were accounted for by service activities (Central Intelligence Agency, 2009).

With regard to the early works in the field of emotional labor, Hochschild (1983) described how flight attendants at Delta Airlines have to possess "Delta Personality" to generate favorable emotional displays. This "Delta Personality" informs them of the expected parts of flight attendants' work roles, which she termed as "emotional labor". Jobs that involve emotional labor include face to face or voice to voice contact with public, producing an emotional state in another person, and allowing employers to exercise a degree of control over the emotional activities of employees (Hochschild, 1983). Rafaeli and Sutton expanded the concepts of emotional labor by proposing two primary determinants of the emotions expressed by a role occupant: (1) societal, occupational, and organizational norms; and (2) characteristics of the role occupant, including dispositions and inner feelings on the job (Rafaeli, 1989; Rafaeli \& Sutton, 1989, 1990; Sutton, 1991; Sutton \& Rafaeli, 1988). Ashforth and Humphrey (1993) redefined emotional labor as the act of displaying the appropriate emotion (i.e., conforming to a display rule). They focused on behaviors rather than on the presumed emotions underlying behaviors because compliance with display 
rules influences service recipients and one may conform to display rules without being forced to manage feelings.

In the past a few decades, researchers' focus on the topic of emotional labor had become rather divergent. For example, Dahling and Johnson (2012) summarized how individual differences influence emotional labor. Specially, an array of studies focused on congruence and fit in emotional labor (e.g., Bono \& Vey, 2005, 2007; Brotheridge \& Lee, 2003; Diefendorff, Croyle, \& Gosserand, 2005; Diefendorff et al., 2011; Gosserand \& Diefendorff, 2005; Liu et al., 2008). Recently, the concept of emotional labor has also been applied and integrated with emotional intelligence literature (e.g., Miao, Humphrey, \& Qian, 2016, 2017a, 2017b, 2017c). Another stream of studies concentrated on motivations and control theory of emotional labor (e.g., Allen et al., 2010; Diefendorff \& Gosserand, 2003, 2005; Diefendorff et al., 2005; Randolph \& Dahling, 2011). Representative work by Diefendorff and Gosserand (2003) demonstrated a successful adaption of control theory model to emotional labor processes. They discussed organizational display rule (i.e., behavioral standards or organizational standards) and how employees modify their emotional display when it is discrepant from display rules. Moreover, because individuals are accustomed to particular behaviors, it is also popular among researchers to investigate how psychological traits influence emotional labor (e.g., Cheung \& Tang, 2009; Chi et al., 2011; Gardner, Fischer, \& Hunt, 2009; Johnson \& Spector, 2007; Judge, Woolf, \& Hurst, 2009; Liu et al., 2008). Another area of interest in emotional labor is on the relationships between emotional labor and employee wellbeing and between emotional labor and performance outcomes (e.g., Ashforth \& Humphrey, 1993; Bono \& Vey, 2007; Brotheridge \& Lee, 2003; Cote, 2005; Diefendorff et al., 2011; Erickson \& Ritter, 2001; Goldberg \& Grandey, 2007; Gosserand \& Diefendorff, 2005; Grandey, 2000; Hochschild, 1983; Rafaeli, 1989; Rafaeli \& Sutton, 1989, 1990; Sutton, 1991; Sutton \& Rafaeli, 1988). Despite the maturity of the research in emotional labor, there are still many critical questions that remain unanswered; in addition, the findings for the links between emotional labor and well-being and performance outcomes have been found inconsistent (Bono \& Vey, 2005; Fisher \& Ashkanasy, 2000; Rubin et al., 2005). Cote (2005) indicated that the understanding of the mechanism linking emotional labor with strain can be limited. Similarly, Pugh, Groth, and Hennig-Thurau (2011) pointed out that the inconsistent conceptualization of emotional dissonance construct in emotional labor research is one reason for existing contradictory findings.

In this paper, we focus on the role of rewards as well as valance and expectancy of display rules, and investigate how they moderate the relationship between emotional labor and employee well-being (i.e., emotional exhaustion and job satisfaction). There are a few studies discussing how financial rewards influence the performance of emotional labor and how emotional performance relates to financial gains. Rafaeli and Sutton (1987) discussed financial well-being as an individually salient outcome. They argued that a maximal smile brings greater tips than a minimal smile. Rafaeli and Sutton also discussed how to use rewards to encourage the display of certain emotions. Diefendorff and Croyle (2008) indicated how reward system influences the motivational force, thus enhancing the display rule commitment. Chi et al. (2011) investigated how performance on acting affects financial gains (e.g., tips). Nevertheless, none of these studies examined how rewards, valance and expectancy of display rules influence the correlation between emotional labor and employee well-being. The present study is intended to fill this void in the literature.

The present study makes several noteworthy contributions to the emotional labor literature. First, we provide insights on the conditions under which the nature of the relationships between emotional labor and well-being outcomes will be affected. We investigate how rewards, valance and expectancy of display rules moderate aforementioned relationships. Second, we classify the rewards into two categories: (a) financial reward and (b) nonfinancial reward. We further investigate the differential moderating impact of these two types of rewards on the aforesaid relationships for different types of emotional workers. Figure 1 is a conceptual model that summarizes the relationships among different constructs investigated in the present study. 
FIGURE 1

A CONCEPTUAL MODEL

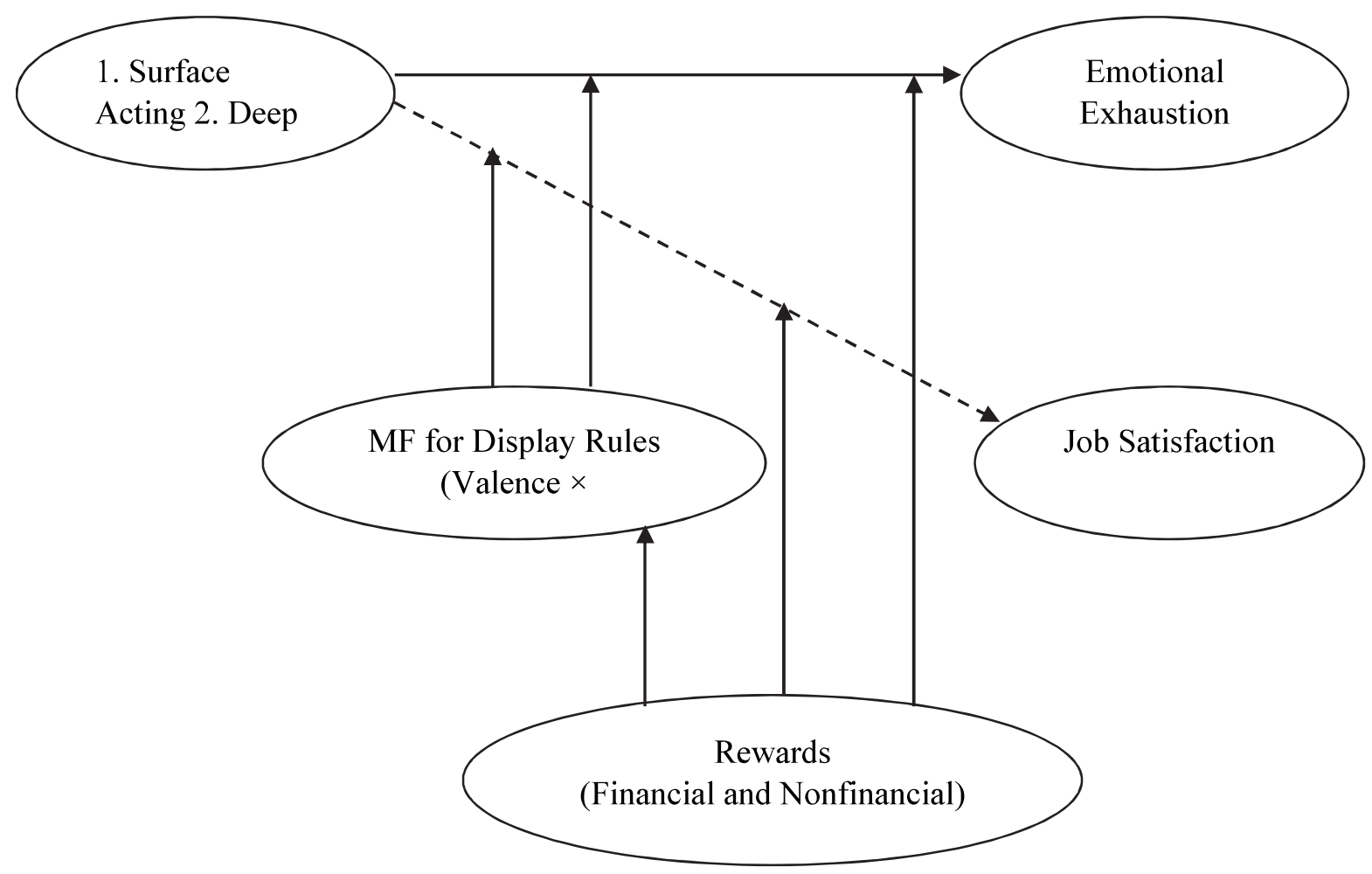

Note. Dash line denotes a negative correlation. $\mathrm{MF}=$ motivational force.

\section{THEORY AND PROPOSITIONS}

\section{Emotional Labor, Ego Depletion, Emotional Dissonance, and Employee Well-Being}

Most of the emotional labor research published in the past three decades revolved around the topics of surface acting, deep acting, ego depletion, emotional dissonance, and employee well-being, which is partly due to the influence of Hochschild's (1983) study. In Hochschild's seminal work, she proposed that when felt emotions differ from expressed emotions, tension will be triggered. This implies that emotional dissonance is a discrepancy between inner feeling and expressive emotion (Pugh et al., 2011). Zerbe (2000) indicated that there are three different aspects of emotional dissonance: expressed emotions, felt emotions, and emotions required by display rules, which lead to different combinations of these aspects in terms of conceptualization of emotional dissonance. Based on Zerbe's arguments, Hulsheger and Schewe (2011) refined the emotional dissonance into two categories: "emotion-rule dissonance" and "fake emotion display". "Emotion-rule dissonance", an antecedent to emotion regulation, stresses the discrepancy between required and felt emotion (Holman, Martinez-Inigo, \& Totterdell, 2008; Morris \& Feldman, 1996). Similarly, "fake emotion display", a consequence of emotion regulation, emphasizes the inconsistency between expressed and felt emotions (Cote, 2005; Van Dijk \& Kirk, 2006). Nevertheless, the majority of researchers treat emotional dissonance as emotion-rule dissonance, which is congruent with theoretical models of emotional labor defining emotional dissonance as an antecedent to surface acting and deep acting (Dormann \& Kaiser, 2002; Holman, Chissick, \& Totterdell, 2002; Holman, Martinez-Inigo, \& Totterdell, 2008; Hulsheger \& Schewe, 2011; Rubin et al., 2005). On the other hand, Diefendorff and Gosserand (2003) pointed out that emotional labor involves ongoing processes of comparing one's emotional display with display rules until the display is deemed appropriate. If emotional discrepancy is detected, emotion regulation mechanisms will be activated and employed by 
individuals until the alignment processes between emotional display and display rules are completed. Then, it elicits the topic of two commonly discussed strategies for regulating one's emotional display, which are surface acting and deep acting.

With regard to surface acting, also known as "faking in bad faith" (Rafaeli \& Sutton, 1987), means that individuals modify and fake their appropriate expressive displays without shaping inner feeling (Grandey, 2003; Grosserand \& Diefendorff, 2005), by which they put on a mask and "paint on" the emotional expression but their true feelings leak out in the form of facial cues and vocal expressions (Ekman, 1985; Pugh, 2001). Further noted is that regulating through surface acting is generally thought to be more detrimental because it brings out a mismatch between inner feeling and expressive display, which triggers a series of negative consequences, for instance, burnout, intentions to quit, and lower job satisfaction (Brotheridge \& Grandey, 2002; Cote \& Morgan, 2002; Grandey, 2003; Grandey, Fisk, \& Steiner, 2005; Heuven \& Bakker, 2003; Morris \& Feldman, 1997; Pugh et al., 2011).

On the other hand, deep acting, also known as "faking in good faith" (Rafaeli \& Sutton, 1987), is an antecedent-focused form of emotion regulation, which enables the individual to adjust their inner feeling to align with required displays, thus generating authentic expressive displays to the audience (Grandey 2000; Grandey, 2003; Grosserand \& Diefendorff, 2005; Hulsheger \& Schewe, 2011). Deep acting is typically considered to be beneficial because individuals who deeply act try to alter their inner feeling to be consistent with display rules, which reduce the discrepancies between actual emotional display and display rules (Diefendorff \& Grosserand, 2003). Another reason for why deep acting will bring about benefits is that it requires less cognitive (e.g., attention) and motivational (e.g., resilience) resources than surface acting (Gross, 1998; Hulsheger \& Schewe, 2011; Richards \& Gross, 1999, 2000; Goldberg \& Grandey, 2007; Totterdell \& Holman, 2003). Therefore, individuals who conduct surface acting need to consistently monitor expressive display, thus draining the mental and motivational resources and creating considerable strain, which directly influences well-being and performance (Cote, 2005; Goldberg \& Grandey, 2007; Grandey, 2003; Hulsheger \& Schewe, 2011; Martinez-Inigo, Totterdell, Alcover, \& Holman, 2007; Zyphur et al., 2007).

Hulsheger and Schewe (2011) noted that whether deep acting consumes more or less mental resources than surface acting remains unanswered in that no extant study have been found to examine the actual cognitive and motivational energy demand of deep and surface acting directly. We may even deem deep acting as an effortful regulatory process that drains mental resources to a certain extent. This indirectly signals our limited understanding of surface acting and deep acting when they are linked to well-being. In addition, Wharton $(1993,1996)$ indicated a positive relationship between emotional labor and employee satisfaction. Brotheridge and Grandey (2002) and Yang and Chang (2008) demonstrated emotional labor links to positive consequences (e.g., higher personal accomplishment and job satisfaction). Pugh et al. (2011) mentioned two studies (Festinger \& Carlsmith, 1959; Steele \& Liu, 1983) which discussed how justifications for behaviors influence the arousal of dissonance. For example, Festinger and Carlsmith (1959) argued that if the justification for behaviors is enough, when participants are paid well for lying, dissonance will not be aroused. Steele and Liu (1983) emphasized that people are capable of tolerating cognitive inconsistency if they can affirm some important aspects of the self. In what follows, we will build on relevant theories and employ them to develop propositions.

\section{Benefits by Performing Emotional Labor}

Within the field of emotional labor, we noted that a few findings cannot generalize across all occupations. In Wharton's (2009) review paper, she mentioned several interesting findings that are relevant to the present study. For instance, Paules (1991) found that restaurant waitresses are not negatively affected by their interactions with customers. Instead, they deemed the management of their emotions as a valuable skill that can be used to gain upper hand in the balance of power with customers. This study implies that gained upper hand will at least partially counteract the negative feelings aroused by engaging in emotional labor for restaurant waitresses. Leidner (1993) suggested that rigid compliance with company's expectations can be at least potentially detrimental to workers' sense of self and identity but she did not find these proposed negative consequences. Results of Leidner's (1993) study indicated 
that salespeople see the benefits of scripted behaviors because they gained valuable techniques for controlling customers, which helps them become more successful. In this study, scripted behaviors can be deemed as organizational display rules, which hints that conforming to display rules brings them beneficial outcomes (e.g., having valuable techniques for controlling customers to make them successful), thus justifying the unpleasant feeling of alienation from self. Lively (2001) found that paralegals are proud of their capability in maintaining self-control in face of stressful demands, which implied that emotional labor may lead to a sense of empowerment or self-enhancement (Leidner, 1993; Stenross \& Kleinman, 1989). Senses of empowerment, self-enhancement, and pride stimulate paralegals to actively engage in emotional labor because these valuable feelings provide them with the justifications for experiencing psychological strain. Ibarra (2002) found that elder care providers feel good when producing authentic emotion in exchange for wage. Wharton (2009) argued that employers will try to manage workers' interactions with customers in frontline service jobs, which may threaten workers' self-concept. However, workers will tactically manage these interactions on the job so as to acquire power and dignity, and meanwhile, withstand degradation. This study implies that when workers attain nonfinancial rewards, such as power, dignity, or promotions in return via engaging in emotional labor, they are less dissatisfied and exhausted because they receive many aforesaid "gifts" to justify their unpleasant feelings. Clancy (2011) indicated that gifts from emotional labor are: beneficial responses around you, coworkers becoming more open, boss becoming more flexible, and customers becoming more loyal, all of which will be beneficial to employee well-being. Further, Ashforth and Humphrey (1993) emphasized that "note that acting per se is not the issue" (p. 99), meaning that acting may not necessarily lead to negative outcomes. They used an example of an introverted salesperson to demonstrate that an introverted salesperson may be motivated to act in an extroverted manner, and in such cases, acting may protect a valued identity.

Based on the review of above examples, it is also noted that reward resulting from acting plays an important role in alleviating the stresses caused by estrangement from employees' true feeling and consumption of mental resources during acting. In this paper, rewards are further classified into two categories: (a) financial and (b) nonfinancial rewards. Financial reward is related to monetary reward (Adelmann, 1995; Ibarra, 2002; Leidner, 1993; Diefendorff \& Gosserand, 2003). Nonfinancial reward is a broad notion, which can consist of feeling of self-competence (Leidner, 1993; Stenross \& Kleinman, 1989), power (Paules, 1991; Wharton, 2009), dignity (Wharton, 2009), admiration (Wharton, 2009), pride (Lively, 2001; Rafaeli \& Sutton, 1991), and joy (Adelmann, 1995), etc. For financial reward gained from doing emotional labor, Adelmann (1995) found out that emotional labor is regarded as beneficial to the amount of tips received and that the potential negative consequences of emotional labor is rated fairly low. Workers also reported nonmonetary rewards such as feeling happy when they were doing their jobs. Diefendorff and Gosserand (2003) indicated that if the organization wants employees to display particular emotions, they need to clarify the value of doing so (e.g., making rewards contingent on emotional displays). Hence, inauthentic feelings aroused by engaging in emotional labor may be externally justified by social and financial rewards because rewards may be viewed as substitute resources to replenish the emotional and energy resources consumed by faking emotion.

\section{Rewards, Valence and Expectancy of Display Rules, and Employee Well-Being \\ Rewards, Valence and Expectancy of Display Rules}

Value and importance of displaying emotions is called as valence of display rules (Diefendorff \& Gosserand, 2003). To be specific, valence of display rules suggested that valence of higher order goals (meeting performance goals in work goal hierarchy and maintaining a desired self-concept in personal goal hierarchy) influences the execution of lower order goals (display rule and displaying felt emotions) (Diefendorff \& Gosserand, 2003). Diefendorff and Gosserand (2003) used an auto salesperson example to indicate that displaying cheery emotions will impact the chance of selling a car, satisfying a customer, and being able to leave early, which leads to high valence of display rules. Obviously, the chance of selling a car, satisfying a customer, and being able to leave early in this example all belong to different types of rewards (i.e., selling a car relates to financial reward; satisfying a customer and being able to leave early 
belong to nonfinancial reward). To illustrate this point, Diefendorff and Croyle (2008) provided empirical support that reward structure is positively related to valence judgment. Their studies suggested that once compensation and praise is linked to positive display, then display rule will become more valuable, thus increasing employees' confidence so that they can better concentrate their efforts on display rule. Further noted is that they cited several studies to discuss why reward will influence the valence of display rules. For instance, Hollenbeck and Klein (1987) suggested that the extent to which a behavior is rewarded and recognized will impact individuals' valence judgments for that behavior. Wright (1992) found that valence mediated the impact of incentives on goal commitment. Klein et al.'s (1999) meta-analytic study showed that incentives are positively correlated with goal commitment.

Linking the concept of valence of display rules to the benefits by doing emotional labor, it is clear that valance of display rules is positively related to rewards from doing emotional labor.

For example, in terms of the financial reward resulted from emotional labor, Leidner's (1993) insurance salespeople example indicated that conforming to display rules via routinized and scripted behaviors brings them financial reward and makes them successful, which leads to positive valence of display rules. Adelmann's (1995) study implies that tips received and feeling happy lead to the positive valence of display rules because of the impact of financial reward and nonfinancial reward (i.e., joy). Ibarra's (2002) study suggested that elder care providers produce authentic emotion in exchange for wage to make them feel good to conduct emotional labor, which implies that wage increases the valence of display rules.

With regard to the nonfinancial reward resulted from emotional labor, for example, Paules's (1991) restaurant waitress example implies that skills of emotion management brings them upper hand in the balance of power with customers, which leads to positive valance of display rule; moreover, this is a case showing power as reward. Lively's (2001) paralegals case implies that capability in maintaining selfcontrol in face of stressful demands by conforming to display rule makes them obtain nonfinancial reward (e.g., pride, power, and feeling of self-competency), which leads to positive valance of display rules. Thus, based on the discussions above, we advance the following proposition.

Proposition 1a: Rewards positively correlate with the valance of display rules.

In addition to the valance of display rules, Diefendorff and Gosserand (2003) also proposed expectancy and motivational force (MF) for displaying emotions (Klein, 1991; Tubbs, Boehne, \& Dahl, 1993; Vroom, 1964). They noted that expectancy refers to how confident a person can perform an emotional display and the expectancy judgment will be influenced by the difficulty of performing an emotional display. MF for displaying the emotion is multiplicatively determined by expectancy and valence. MF will be high when both valence and expectancy are high; when either one of them is low, MF will be low. They further provided the implications that if organizations want employees to display particular emotions, they should clarify the value of doing so (i.e., valance) and increase employees' beliefs that they are able to do so (i.e., expectancy). Gray and McNaughton (2000) indicated that individuals will put forth more effort and attention when rewards are connected to behaviors. Diefendorff and Croyle (2008) suggested that when rewards are linked to emotional displays, it may lead individuals to allocate more resources to displaying emotions because the display is valuable due to the reward. Then, this increases the confidence they have in displaying emotions. On the other hand, when rewards are not tied to emotional display, reported expectancy can be relatively low. Moreover, they provided empirical support that reward structure is positively related to expectancy judgments. Based on the above discussions, we offer the following propositions.

Proposition 1b: Rewards positively correlate with the expectancy of display rules.

Proposition 1c: Rewards positively correlate with the MF of display rules. 


\section{MF of Display Rules and Rewards as Moderators}

Surface acting will lead to emotional exhaustion and job dissatisfaction because purposeful selfcontrol and regulatory processes in surface acting are effortful and deplete mental resources (Baumeister et al., 1998; Muraven, Tice, \& Baumeister, 1998). However, rewards may possibly moderate this correlation in such a way that once rewards are high, the correlations for surface acting with emotional exhaustion and job dissatisfaction can become weak. To illuminate this point, Chi, Grandey, Diamond, and Krimmel (2011) discussed how financial incentives provide the justification for the unpleasant feelings caused by emotional labor. They cited several early studies to explore this justification effect. For example, Festinger and Carlsmith's (1959) study suggested financial incentive, as a justification for participation, can reduce the unpleasant feeling caused by cognitive dissonance for the participants. Bem's (1967) self-perception theory showed that when external forces (e.g., incentives) are absent, people's self-concept will be shaken and unpleasant feeling will be aroused. Similarly, by revisiting the benefits from doing emotional labor, it is clear that financial (Adelmann, 1995; Leidner, 1993; Diefendorff \& Gosserand, 2003) and nonfinancial rewards resulted from doing emotional labor, such as feeling of self-competence (Leidner, 1993; Stenross \& Kleinman, 1989), power (Paules, 1991; Wharton, 2009), dignity (Wharton, 2009), admiration (Wharton, 2009), pride (Lively, 2001; Rafaeli \& Sutton, 1991), and joy (Adelmann, 1995), will provide the justifications for ego depletion and replenish the mental resources so that engaging in emotional labor will be less dissatisfying and strenuous. Thus, rewards will weaken the links for surface acting, emotional exhaustion, and job dissatisfaction. It is plausible that MF for display rules will also moderate the aforementioned links because MF for display rules has similar characteristics like rewards (e.g., high MF for display rules implies high value of displaying emotions [Diefendorff \& Croyle, 2008]) according to what have been discussed above.

However, on the other hand, deep acting is typically considered to be beneficial (Diefendorff \& Grosserand, 2003). Hulsheger and Schewe's (2011) meta-analytic study also demonstrated that there is no link between deep acting, personal ill-being, and job-related well-being. Thus, we predict that rewards as well as MF of display rules will not condition the links between deep acting, emotional exhaustion, and job satisfaction. Thus, we present the following propositions.

Proposition 2a: Rewards will moderate the correlations between surface acting, emotional exhaustion, and job satisfaction in such a way that the correlations become weaker when rewards are high. However, correlations between deep acting, emotional exhaustion, and job satisfaction do not depend on rewards.

Proposition 2b: MF for display rules will moderate the correlations between surface acting, emotional exhaustion, and job satisfaction in such a way that the correlations become weaker when MF for display rules is high. However, correlations between deep acting, emotional exhaustion, and job satisfaction do not depend on MF for display rules.

\section{Rewards, Types of Emotional Workers, and Employee Well-Being}

Professions are portrayed by their expertise, power, authority (Abbott 1988; Freidson 1994), and qualities that are reproduced in part through interactions on the job (Wharton, 2009). It is noted that employees in some occupations (e.g., emotion managers, lawyers, doctors, and professors, etc.) will have high autonomy in their positions so that they can exercise control and monitor over the interactions with customers. This means employers will have little authority over workers' interactions with customers and employers cannot regulate these interactions (Paules, 1991; Macdonald \& Sirianni, 1996).

In contrast to emotional professionals mentioned above, Macdonald and Sirianni (1996) used the term "emotional proletariat" to denote the workers who have little formal power and subject to employers' attempt to monitor and control their interactions. Their research instigated many studies on emotional proletariat. For instance, Leidner (1999) described emotional proletarians as the frontline service workers who are prone to be guided by employers rather than professional norms. This means employers will intervene and supervise their interactive service job. Ibarra (2002) and Leidner (1993) argued that emotional proletarians can refer to the frontline workers whose behaviors are scripted; examples can be 
service workers such as flight attendants, sales clerks, and fast food servers who have fleeting contact with their customers. Bolton (2004) said that emotional proletariat refers to the employees participating in "routinized" niceness in the mass service sector. Bradley et al. (2000) and Warhurst and Nickson (2007) further refined the definition of emotional proletariat and explained they are subordinate to customers, with low social status, and possessing no or little capacity to shape the encounter. Payne (2009) noted that the vast majority of front-line service workers are often regarded as emotional proletariats. To sum up, the distinct features of emotional proletariats are: low pay; low power and social status; subject to control, monitor, and intervention from supervisors; behaviorally scripted and routinized; subordinate to customers; and dealing with fleeting, massive contacts with customers.

To draw a distinction between emotional proletariats and emotional professionals, Macdonald and Sirianni (1996) emphasized that there are several kinds of jobs in service industry: large numbers of low pay, low-skill jobs; a smaller number of high-skill, high-income jobs; and very few jobs that could be classified in the middle. Leidner (1999) drew a distinction between emotional proletariats and emotional professionals by emphasizing that emotional proletariats have to cope with their own emotions while trying to manage the emotional responses of others. Orzechowicz (2008) provided a summary of typical emotional proletariats, such as insurance agents and fast-food employees (Leidner, 1993, 1999); front-line workers in health and banking industries (Bulan, Erickson, \& Wharton, 1997); care assistant workers (Treweek, 1996); paralegals (Pierce, 1995); bill collectors (Sutton, 1991); waitresses (Paules, 1991); store clerks (Rafaeli \& Sutton, 1990; Rafaeli, 1989); and Disneyland park attendants (Van Maanen \& Kunda, 1989). He further argued that emotional proletariats engage in high levels of interaction between workers and customers. They represent the public face of the company and subject to organizational feeling rules. Their behaviors are highly scripted and managed (Leidner, 1993). He also drew a distinction between emotional proletariats and emotional professionals by arguing that emotional professionals have more collective feeling and their emotional labor is more self-directed instead of being organizationally monitored. He suggested that relative autonomy of professional, managerial feeling management and resources to manage emotions (e.g., social network that allows venting [Hochschild, 1983]; organizational supports in managing emotions) can lead to privileged status, thus differentiating emotional proletariats and emotional professionals. In conclusion, emotional professionals typically have high autonomy in their jobs, high skill, self-directedness, high pay, and high social status. Examples of emotional professionals are: emotion managers, therapists, lawyers, doctors, and professors (Hochschild, 1983; Orzechowicz, 2008; Wharton, 2009).

Chi et al. (2011) argued that wages earned from doing prototypical emotional labor is low (Glomb, Kammeyer-Mueller, \& Rotundo, 2004) and such employees engaging in prototypical emotional labor greatly need and value financial rewards; further, they are satisfied by such financial opportunities (Locke, 1976). For example, behaviors of McDonald's workers are tightly scripted and they have little autonomy and control over their mood or temperament (Leidner, 1993). This is a low-paid job and customers often ignore the interactions with McDonald workers because what customers need is just to get their food as quick as possible. In addition, due to McDonald workers' ambiguous roles and placements in low power positions, they have limited opportunities to attain nonfinancial rewards, such as respect, dignity, and pride, etc. Hence, the job itself does not have much intrinsic values to compensate for the unpleasant feelings caused by emotional labor. Under this circumstance, financial reward is obviously important for them to justify the personal and job-related ill-being caused by emotional labor. On the other hand, emotional professionals will have more types of rewards than emotional proletariats. For example, besides earning salary as financial reward, lawyers will also attain power, feeling of competency, respect, dignity, admiration, and pride as their nonfinancial rewards. Thus, financial rewards may not be significantly critical to them and they will not be quite satisfied if only financial reward is secured because they want to pursue much higher order goals than emotional proletariats. Therefore, it is quite possible for them to allocate their attentions on both financial and nonfinancial rewards in a balanced manner. In contrast, emotion proletariats are prone to have one-sided preferences for financial rewards. Hence, we offer following propositions. 
Proposition 3a: Moderating impact of financial reward on the correlations between surface acting, emotional exhaustion, and job satisfaction will be stronger for emotional proletariats than emotional professionals.

Proposition 3b: Moderating impact of nonfinancial reward on the correlations between surface acting, emotional exhaustion, and job satisfaction will be stronger for emotional professionals than emotional proletariats.

\section{CONCLUSION}

Our study demonstrated that rewards, in both financial and nonfinancial forms, can relieve the stresses and unpleasant feelings caused by doing emotional labor. This implies that rewards do act as justifications for doing emotional labor, especially for surface acting, in such a way that when rewards are high, surface acting is less detrimental to individuals' well-being. Another noteworthy point is that high rewards will lead to high MF for display rules, which implies that when rewards are high, emotional workers are more likely to embrace organizational display rules. Because they believe embracing organizational display rules will lead to better outcomes (e.g., making a big sale), this belief (i.e., MF) will serve as similar functions like incentives to alleviate unpleasant feelings caused by engaging in surface acting, which signals the moderating impact.

Moreover, this study also provides implications that different emotional workers will have different thinking toward the value of different types of rewards. Emotional professionals in well-paid, wellrespected positions may allocate their attentions on financial and nonfinancial rewards in a balanced manner. On the other hand, emotional proletariats may have one-sided preferences for financial reward as a major justification for personal and work-related ill-being caused by emotional labor. This suggests differential moderation impact of financial and nonfinancial rewards on the relationships between surface acting, emotional exhaustion, and job satisfaction for emotional professionals and emotional proletariats.

The present study provides theoretical implications in terms of how rewards influence MF for display rules, how rewards and MF for display rules act as moderators, and differential moderation impacts of financial and nonfinancial rewards, on the relationships between surface acting, emotional exhaustion, and job satisfaction. This study also provides managerial implications with respect to how companies can employ rewards, improve organizational policies, and optimize reward structure for different emotional workers to enhance personal and work-related well-being.

\section{NOTE}

Both Shanshan Qian and Chao Miao are first authors and corresponding authors. They equally contributed to this paper. 


\section{REFERENCES}

Abbott, A. (1988). The system of professions: An essay on the division of expert labor. Chicago: University of Chicago Press.

Adelmann, P. K. (1995). Emotional labor as a potential source of job stress. Organizational risk factors for job stress. In L. S. Sauter \& L. R. Murphy (Eds.), Organizational risk factors for job stress, (pp. 371-381). Washington, DC, US: American Psychological Association.

Allen, J. A., Pugh, S. D., Grandey, A. A., \& Groth, M. (2010). Following display rules in good or bad faith? Customer orientation as a moderator of the display rule-emotional labor relationship. Human Performance, 23, 101-115.

Ashforth, B. E., \& Humphrey, R. H. (1993). Emotional labor in service roles: The influence of identity. Academy of Management Review, 18, 88-115.

Ashforth, B. E. (1989). Of canned laughter and political handlers: The erosion of spontaneity and authenticity in social life. Annual meeting of the Canadian Psychological Association, Halifax, Nova Scotia.

Baumeister, R. F., Bratslavsky, E., Muraven, M., \& Tice, D. M. (1998). Ego depletion: Is the active self a limited resource? Journal of Personality and Social Psychology, 74, 12521265.

Bolton, S. (2004). Conceptual confusions: Emotion work as skilled work. In C. Warhurst, I. Grugulis, \& E. Keep (Eds.), The skills that matter (pp. 19-37). Basingstone: Palgrave Macmillan.

Bono, J. E., \& Vey, M. A. (2005). Toward understanding emotional management at work: A quantitative review of emotional labor research. In C. E. Hartel, W. J. Zerbe, \& N. M. Ashkanasy (Eds.), Emotions in organizational behavior (pp. 213-233). Mahwah, NJ: Erlbaum Publishers.

Bono, J. E., \& Vey, M. A. (2007). Personality and emotional performance: Extraversion, neuroticism, and self-monitoring. Journal of Occupational Health Psychology, 12, $177-$ 192.

Brotheridge, C. M., \& Grandey, A. A. (2002). Emotional labor and burnout: Comparing two perspectives of "people work." Journal of Vocational Behavior, 60, 17-39.

Brotheridge, C. M., \& Lee, R. T. (2003). Development and validation of the Emotional Labour Scale. Journal of Occupational and Organizational Psychology, 76, 365-379.

Bulan, H. F., Erickson, R., \& Wharton, A. S. (1997). Doing the job for others: The affective requirements of service work, gender, and emotional well-Being. Social Problems, 44, 235-256.

Central Intelligence Agency. (2009). The world factbook 2009. Central Intelligence Agency.

Cheung, F. Y., \& Tang, C. S. (2009). The influence of emotional intelligence and affectivity on emotional labor strategies at work. Journal of Individual Differences, 30, 75-86.

Chi, N.-W., Grandey, A. A., Diamond, J. A., \& Krimmel, K. R. (2011). Want a tip? Service performance as a function of emotion regulation and extraversion. Journal of Applied Psychology, 96, 1337-1346.

Clancy, A. B. (2011). The success gurus: 17 lessons in greatness from the best minds in business. New York, NY: Portfolio.

Cote, S., \& Morgan, L. M. (2002). A longitudinal analysis of the association between emotion regulation, job satisfaction, and intentions to quit. Journal of Organizational Behavior, 23, 947-962. 
Cote, S. (2005). A social interaction model of the effects of emotion regulation on work strain. Academy of Management Review, 30, 509-530.

Dahling, J. J., \& Johnson, H.-A. (2012). Motivation, fit, confidence, and skills: How do individual differences influence emotional labor? In A. Grandey, J. Diefendorff, \& D. Rupp (Eds.), Emotional labor in the 21st century: Diverse perspectives on emotion regulation at work. New York, NY: Psychology Press/Routledge.

Diefendorff, J. M., Croyle, M. H., \& Gosserand, R. H. (2005). The dimensionality and antecedents of emotional labor strategies. Journal of Vocational Behavior, 66, 339-357.

Diefendorff, J. M., \& Croyle, M. H. (2008). Antecedents of emotional display rule commitment. Human Performance, 21, 310-332.

Diefendorff, J. M., Erickson, R. J., Grandey, A. A., \& Dahling, J. J. (2011). Emotional display rules as work unit norms: A multilevel analysis of emotional labor among nurses. Journal of Occupational Health Psychology, 16, 170-186.

Diefendorff, J. M., \& Gosserand, R. H. (2003). Understanding the emotional labor process: A control theory perspective. Journal of Organizational Behavior, 24, 945-959.

Dormann, C., \& Kaiser, D. M. (2002). Job conditions and customer satisfaction. European Journal of Work and Organizational Psychology, 11, 257-283.

Ekman, P. (1985). Telling lies. New York: Norton.

Erickson, R. J., \& Ritter, C. (2001). Emotional labor, burnout, and inauthenticity: Does gender matter? Social Psychology Quarterly, 64, 146-163.

Festinger, L., \& Carlsmith, J. M. (1959). Cognitive consequences of forced compliance. Journal of Abnormal and Social Psychology, 58, 203-210.

Fisher, C. D., \& Ashkanasy, N. M. (2000). The emerging role of emotions in work life: An introduction. Journal of Organizational Behavior, 21, 123-129.

Freidson, E. (1994). Professionalism reborn: Theory, prophecy, and policy. Chicago: University of Chicago Press.

Gardner, W. L., Fischer, D., \& Hunt, J. G. (2009). Emotional labor and leadership: A threat to authenticity? The Leadership Quarterly, 20, 466-482.

Glomb, T. M., Kammeyer-Mueller, J. D., \& Rotundo, M. (2004). Emotional labor demands and compensating wage differentials. Journal of Applied Psychology, 89, 700-714.

Goldberg, L. S., \& Grandey, A. A. (2007). Display rules versus display autonomy: Emotion regulation, emotional exhaustion, and task performance in a call center simulation. Journal of Occupational Health Psychology, 12, 301-318.

Gosserand, R. H., \& Diefendorff, J. M. (2005). Emotional display rules and emotional labor: The moderating role of commitment. Journal of Applied Psychology, 90, 1256-1264.

Grandey, A. A. (2000). Emotion regulation in the workplace: A new way to conceptualize emotional labor. Journal of Occupational Health Psychology, 5, 95-110.

Grandey, A. A. (2003). When "the show must go on": Surface acting and deep acting as determinants of emotional exhaustion and peer-rated service delivery. Academy of Management Journal, 46, 86-96.

Grandey, A. A., Fisk, G. M., \& Steiner, D. D. (2005). Must "service with a smile" be stressful?

The moderating role of personal control for U.S. and French employees. Journal of Applied Psychology, 90, 893-904.

Gray, J. A., \& McNaughton, N. (2000). The neuropsychology of anxiety: An enquiry into the functions of the septo-hippocampal system (2nd ed.). New York: Oxford University Press. 
Gross, J. J. (1998). The emerging field of emotion regulation: An integrative review. Review of General Psychology, 2, 271-299.

Heuven, E., \& Bakker, A. B. (2003). Emotional dissonance and burnout among cabin attendants. European Journal of Work and Organizational Psychology, 12, 81-100.

Hochschild, A. R. (1983). The managed heart: Commercialization of human feelings. University of California Press, CA: Berkeley.

Hollenbeck, J. R., \& Klein, H. J. (1987). Goal commitment and the goal-setting process: Problems, prospects, and proposals for future research. Journal of Applied Psychology, 72, 212-220.

Holman, D., Chissick, C., \& Totterdell, P. (2002). The effects of performance monitoring on emotional labor and well-being in call-centers. Motivation and Emotion, 26, 57-81.

Holman, D., Martinez-Inigo, D., \& Totterdell, P. (2008). Emotional labour and employee wellbeing: An integrative review. In N. M. Ashkanasy \& C. L. Cooper (Eds.). Research companion to emotion in organizations (pp. 301-315). Northampton, MA: Edward Elgar Publishing.

Hulsheger, U. R., \& Schewe, A. F. (2011).On the costs and benefits of emotional labor: A metaanalysis of three decades of research. Journal of Occupational Health Psychology, 16, 361-389.

Ibarra, M. (2002). Emotional proletarians in a global economy: Mexican immigrant women and elder care work. Urban Anthropology and Studies of Cultural Systems and World Economic Development, 31, 317-350.

Johnson, H. M., \& Spector, P. E. (2007). Service with a smile: Do emotional intelligence, gender, and autonomy moderate the emotional labor process? Journal of Occupational Health Psychology, 12, 319-333.

Judge, T. A., Woolf, E. F., \& Hurst, C. (2009). Is emotional labor more difficult for some than others? A multilevel, experience-sampling study. Personnel Psychology, 62, 57-88.

Klein, H. J. (1991). Further evidence on the relationship between goal setting and expectancy theories. Organizational Behavior and Human Decision Processes, 49, 230-257.

Klein, H. J., Wesson, M. J., Hollenbeck, J. R., \& Alge, B. J. (1999). Goal commitment and the goal-setting process: Conceptual clarification and empirical synthesis. Journal of Applied Psychology, 84, 885-896.

Leidner, R. (1993). Fast food, fast talk: Service work and the routinization of everyday life. Berkeley: University of California Press.

Leidner, R. (1999). Emotional labor in service work. The Annals of the American Academy of Political and Social Science, 561, 81-95.

Liu, Y., Prati, L. M., Perrewé, P. L., \& Ferris, G. R. (2008). The relationship between emotional resources and emotional labor: An exploratory study. Journal of Applied Social Psychology, 38, 2410-2439.

Lively, K. J. (2001). Occupational claims to professionalism: The case of paralegals. Symbolic Interactions, 24, 343-365.

Locke, E. A. (1976). The nature and causes of job satisfaction. In M. D. Dunnette (Ed.), Handbook of industrial and organizational psychology (pp. 1293-1349). Chicago: Rand McNally.

Macdonald, C. L., \& Sirianni, C. (1996). The service society and the changing experience of work. In C. L. Macdonald \& C. Sirianni (Eds.), Working in the Service Society (pp. 126). Philadelphia, PA: Temple University Press. 
Martinez-Inigo, D., Totterdell, P., Alcover, C. M., \& Holman, D. (2007). Emotional labour and emotional exhaustion: Interpersonal and intrapersonal mechanisms. Work and Stress, 21, $30-47$.

Mehring J. (2006). Even more help wanted. Business Week, 3981, 26.

Miao, C., Humphrey, R. H., \& Qian, S. (2016). Leader emotional intelligence and subordinate job satisfaction: A meta-analysis of main, mediator, and moderator effects. Personality and Individual Differences, 102, 13-24.

Miao, C., Humphrey, R. H., \& Qian, S. (2017a). A meta-analysis of emotional intelligence and work attitudes. Journal of Occupational and Organizational Psychology, 90, 177-202.

Miao, C., Humphrey, R. H., \& Qian, S. (2017b). Are the emotionally intelligent good citizens or counterproductive? A meta-analysis of emotional intelligence and its relationships with organizational citizenship behavior and counterproductive work behavior. Personality and Individual Differences, 116, 144-156.

Miao, C., Humphrey, R. H., \& Qian, S. (2017c). A meta-analysis of emotional intelligence effects on job satisfaction mediated by job resources, and a test of moderators. Personality and Individual Differences, 116, 281-288.

Morris, J. A., \& Feldman, D. C. (1996). The dimensions, antecedents, and consequences of emotional labor. Academy of Management Review, 21, 986-1010.

Muraven, M., Tice, D. M., \& Baumeister, R. F. (1998). Self-control as a limited resource: Regulatory depletion patterns. Journal of Personality and Social Psychology, 74, 774789.

Orzechowicz, D. (2008). Privileged emotion managers: The case of actors. Social Psychology Quarterly, 71, 143-156.

Payne, J. (2009). Emotional labour and skill: A reappraisal. Gender, Work and Organization, $16,348-367$.

Paules, G. F. (1991). Dishing it out: Power and resistance among waitresses in a New Jersey restaurant. Philadelphia, PA: Temple University Press.

Pierce, J. L. (1995). Gender trials: Emotional lives in contemporary law firms. Berkeley, CA: University of California Press.

Pugh, S. D., Groth, M., \& Hennig-Thurau, T. (2011). Willing and able to fake emotions: A closer examination of the link between emotional dissonance and employee well-being. Journal of Applied Psychology, 96, 377-390.

Pugh, S. D. (2001). Service with a smile: Emotional contagion in the service encounter. Academy of Management Journal, 44, 1018-1027.

Rafaeli, A. (1989). When clerks meet customers: A test of variables related to emotional expression on the job. Journal of Applied Psychology, 74, 385-393.

Rafaeli, A., \& Sutton, R. I. (1989). The expression of emotion in organizational life. In L. L. Cummings \& B. M. Staw (Eds.), Research in organizational behavior (pp.1-42). Greenwich, CT: JAI Press.

Rafaeli, A., \& Sutton, R. I. (1990). Busy stores and demanding customers: How do they affect the display of positive emotion? Academy of Management Journal, 33, 623-637.

Randolph, K. L., \& Dahling, J. J. (2011). Proactive personality and task significance in the emotional labor process. $26^{\text {th }}$ Annual Conference of the Society for Industrial and Organizational Psychology, Chicago, IL.

Richards, J. M., \& Gross, J. J. (1999). Composure at any cost? The cognitive consequences of emotion suppression. Personality and Social Psychology Bulletin, 25, 1033-1044. 
Richards, J. M., \& Gross, J. J. (2000). Emotion regulation and memory: The cognitive costs of keeping one's cool. Journal of Personality and Social Psychology, 79, 410-424.

Rubin, R. S., Staebler Tardino, V. M., Daus, C. S., \& Munz, D. C. (2005). A reconceptualization of the emotional labor construct: On the development of an integrated theory of perceived emotional dissonance and emotional labor. In C. E. J. Hartel, W. J. Zerbe, \& N. M. Ashkanasy (Eds.), Emotions in organizational behavior (pp. 189-211). Mahwah, NJ: Erlbaum.

Steele, C. M., \& Liu, T. J. (1983). Dissonance processes as self-affirmation. Journal of Personality and Social Psychology, 45, 5-19.

Stenross, B., \& Kleinman, S. (1989). The highs and lows of emotional labor: Detectives' encounters with criminals and victims. Journal of Contemporary Ethnography, 17, 435452.

Sutton, R. I. (1991). Maintaining norms about expressed emotions: The case of bill collectors. Administrative Science Quarterly, 36, 245-268.

Sutton, R. I., \& Rafaeli, A. (1988). Untangling the relationship between displayed emotions and organizational sales: The case of convenience stores. Academy of Management Journal, 31, 461-487.

Totterdell, P., \& Holman, D. (2003). Emotion regulation in customer service roles: Testing a model of emotional labor. Journal of Occupational Health Psychology, 8, 55-73.

Treweek, G. L. (1996). Emotion work in care assistant work. In V. James \& J. Gabe (Eds.), Health and the sociology of emotions (pp.115-132). MA: Blackwell.

Tubbs, M. E., Boehne, D. M., \& Dahl, J. G. (1993). Expectancy, valence, and motivational force functions in goal-setting research: An empirical test. Journal of Applied Psychology, 78, 361-373.

Van Dijk, P. A., \& Kirk, A. (2006). Emotional labour and negative job outcomes: An evaluation of the mediating role of emotional dissonance. Journal of Management \& Organization, 12, 101-115.

Van Maanen, J., \& Kunda, G. (1989). "Real feelings": Emotional expression and organizational culture. In L.L. Cummings \& B. M. Staw (Eds.), Research in Organizational Behavior (pp. 43-103). Greenwich, CT: JAI.

Vroom, V. H. (1964). Work and motivation. New York: Wiley.

Warhurst, C., \& Nickson, D. (2007). A new labour aristocracy? Aesthetic labour and routine interactive service. Work, Employment and Society, 21, 785-798.

Wharton, A. S. (1993). The affective consequences of service work: Managing emotions on the job. Work and Occupations, 20, 205-232.

Wharton, A. S. (1996). Service with a smile: Understanding the consequences of emotional labor. In C. L. Macdonald \& C. Sirianni (Eds.), Working in the service society (pp. 91112). Philadelphia, PA: Temple University Press.

Wharton, A. S. (2009). The sociology of emotional labor. Annual Review of Sociology, 35, 147165.

Wright, P. M. (1992). An examination of the relationships among monetary incentives, goal level, goal commitment, and performance. Journal of Management, 18, 677-693.

Yang, F. H., \& Chang, C. (2008). Emotional labour, job satisfaction and organizational commitment amongst clinical nurses: A questionnaire survey. International Journal of Nursing Studies, 45, 879-887. 
Zerbe, W. J. (2000). Emotional dissonance and employee well-being. In N. M. Ashkanasy (Ed.), Emotions in the workplace: Research, theory, and practice (pp. 189-214). Westport, CT: Quorum Books/Greenwood Publishing Group.

Zyphur, M. J., Warren, C. R., Landis, R. S., \& Thoresen, C. J. (2007). Self-regulation and performance in high-fidelity simulations: An extension of ego-depletion research. Human Performance, 20, 103-118.

78 American Journal of Management Vol. 17(7) 2017 